\title{
Alterations in 3,3',5'-Triiodothyronine Metabolism in Response to Propylthiouracil, Dexamethasone, and Thyroxine Administration in Man
}

\author{
Jonathan S. LoPresti, Andrea Eigen, Elaine Kaptein, Kenneth P. Anderson, Carole A. Spencer, and John T. Nicoloff \\ Department of Medicine, University of Southern California (USC) School of Medicine and \\ the Los Angeles County/USC Medical Center, Los Angeles, California 90033
}

\begin{abstract}
To elucidate the mechanisms involved in altering serum $3,3^{\prime}, 5^{\prime}$-triiodothyronine $\left(\mathbf{r T}_{3}\right)$ levels with absolute or relative low 3,5,3'-triiodothyronine $\left(\mathrm{T}_{3}\right)$ states in man, agents capable of lowering circulating $\mathbf{T}_{3}$ levels were sequentially administered to six euthyroid subjects. These agents included propylthiouracil (PTU) $(300 \mathrm{mg} / 6 \mathrm{~h} \times 5 \mathrm{~d})$, dexamethasone (DEX) $(2 \mathrm{mg} / 6 \mathrm{~h} \times 5 \mathrm{~d})$, and thyroxine $\left(\mathrm{T}_{4}\right)(3.0 \mathrm{mg}$ load and $0.3 \mathrm{mg} / \mathrm{d} \times 5 \mathrm{~d}) .\left[{ }^{125} \mathrm{I}\right] \mathrm{rT}_{3}$ clearance rates and $\mathrm{rT}_{3}$ production rates were then determined. Increased serum $r \mathbf{T}_{3}$ levels and $\mathrm{rT}_{3} / \mathrm{T}_{4}$ values occurred with both PTU and DEX as compared with control, while $T_{4}$ increased serum $r T_{3}$ but did so without changing $r T_{3} / T_{4}$ values. The $r T_{3}$ clearance rate was significantly decreased by PTU without altering production rate, while DEX increased the $\mathbf{r T}_{3}$ production rate without altering the $r T_{3}$ clearance rate. $T_{4}$ administration did not change $r T_{3}$ clearance but proportionately increased $r \mathrm{r}_{3}$ production. These responses indicate that circulating $\mathrm{rT}_{3}$ predominantly originates from a non-PTU inhibitable deiodinase enzyme system located in extrahepatic tissues. This enzyme system appears to have a high capacity and low affinity for $T_{4}$ and can be stimulated by DEX administration.
\end{abstract}

\section{Introduction}

The peripheral metabolism of thyroxine $\left(\mathrm{T}_{4}\right)^{1}$ in man is a complex process appearing to be of central importance in the regulation of thyroid hormone activation and action. Although this process is concerned with the generation of the active metabolite $3,5,3^{\prime}$-triiodothyronine $\left(T_{3}\right)$ via outer ring or 5 -monodeiodination of $\mathrm{T}_{4}$, an approximately equal portion of $\mathrm{T}_{4}$ is also deiodinated to the apparently inactive metabolite $3,3^{\prime}, 5^{\prime}$-triiodothyronine $\left(\mathrm{rT}_{3}\right)$ by inner ring or 5-deiodination. Further, it is estimated that the combined generation of $\mathrm{T}_{3}$ and $\mathrm{rT}_{3}$ from $\mathrm{T}_{4}$ accounts for $\sim 80 \%$ of $\mathrm{T}_{4}$ disposal in the euthyroid state while the remaining $20 \%$ apparently occurs by a variety of alternate pathways including sulfate and glucuro-

Address reprint requests to Dr. Nicoloff, University of Southern California School of Medicine, 2025 Zonal Avenue, Los Angeles, CA 90033.

Received for publication 22 February 1988 and in revised form 31 May 1989.

1. Abbreviations used in this paper: DEX, dexamethasone; PTU, propylthiouracyl; $\mathrm{T}_{4}$, thyroxine; $\mathrm{rT}_{3}, 3,3^{\prime}, 5^{\prime}$-triiodothyronine; $\mathrm{T}_{3}, 3,5,3^{\prime}$ triiodothyronine.

\footnotetext{
J. Clin. Invest.

(C) The American Society for Clinical Investigation, Inc.

0021-9738/89/11/1650/07 \$2.00

Volume 84, November 1989, 1650-1656
}

nide conjugation, conversion to acetic acid analogues, and ether-link cleavage (1-4).

Alterations in the normal pattern of peripheral $\mathrm{T}_{4}$ metabolism commonly occur in response to a variety of nonthyroidal illnesses, fasting, administration of various pharmacologic agents as well as with $T_{4}$ excess states $(5-12)$. In all but the latter case, there is either an absolute or relative fall in $T_{3}$ production and, in turn, serum $T_{3}$ levels. Concomitant with the fall in serum $T_{3}$ levels, there is usually a reciprocal increase in circulating $\mathrm{rT}_{3}$ values suggesting a shift from activating to inactivating pathways for peripheral $\mathrm{T}_{4}$ metabolism. However, in those conditions thus far studied, such as nonthyroidal illness, liver disease, and fasting, the rise in serum $\mathrm{rT}_{3}$ values has been found by tracer kinetic studies to be secondary to a decrease in $\mathrm{rT}_{3}$ clearance rather than by an increase in the level of $\mathrm{rT}_{3}$ production (13-16). Since these are also conditions associated with reduced $T_{3}$ production, it suggests that there must be a compensatory increase in $T_{4}$ metabolism by the alternate pathways.

The purpose of the present study is to determine whether various pharmacologic agents, which have been previously described as producing absolute or relative reductions in serum $\mathrm{T}_{3}$ levels, raise $\mathrm{rT}_{3}$ values by increasing its production or decreasing its clearance or both. The agents tested included propylthiouracil (PTU), dexamethasone (DEX), and $T_{4}(7-12)$. If the changes observed are similar in character to those previously described in nonthyroidal illnesses and fasting, it can be inferred that a common mechanism for elevating serum $\mathrm{rT}_{3}$ levels may be involved in all low $\mathrm{T}_{3}$ states. Further, the administration of these agents may allow a more precise estimation of the magnitude and character of the alternate pathways for $\mathrm{T}_{4}$ disposal.

\section{Methods}

Six healthy euthyroid male subjects, ages 24-56 yr, participated in this study. Written informed consent was obtained from each volunteer before the initiation of the protocol. All studies were approved by the Institutional Review Board of the Los Angeles County/USC Medical Center and conducted on the General Clinical Research Center of that institution.

Protocol. Subjects underwent a series of four studies over a period of $3 \mathrm{wk}$ as outlined in Fig. $1.1 \mathrm{~d}$ before and daily throughout the duration of the study, each subject received 10 drops of a saturated solution of potassium iodide orally to prevent thyroidal uptake and recycling of radioiodine. At $\mathbf{0 9 0 0}$ hours on the morning of each study period, the subject was given 1 liter of water orally to insure adequate urine flow. A 21-gauge scalp vein needle was placed in a peripheral arm vein and maintained patent with a heparin solution $(25 \mathrm{U} / \mathrm{ml})$. At 1000 hours an intravenous bolus injection of $20 \mu \mathrm{Ci}$ of $\left[{ }^{125} \mathrm{I}\right] \mathrm{rT}_{3}$ ( $\sim 700 \mu \mathrm{Ci} / \mu \mathrm{g}$; Abbott Laboratories, North Chicago, IL) was given. Before the injection, the $\left[{ }^{125} \mathrm{I}\right] \mathrm{rT} \mathrm{T}_{3}$ had been passed through a $0.22-\mu \mathrm{m}$ millipore filter (Millipore Corp., Bedford, MA) to insure sterility. Blood samples were obtained at $-15,0,2,10,20,30,60,90,120,180$, 
$\downarrow$ Injection 1251 rT3

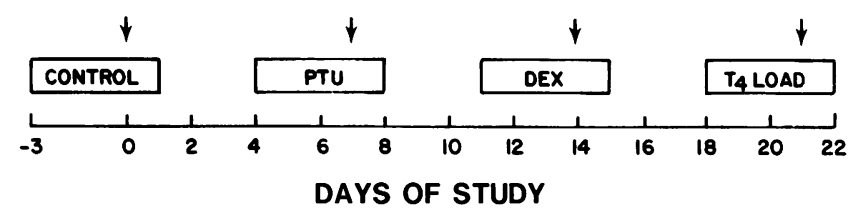

Figure 1. Experimental protocol for determining the effects of PTU, $\mathrm{DEX}$, and $\mathrm{T}_{4}$ on $\mathrm{rT}_{3}$ clearance and production. Each arrow represents an injection of $\left[{ }^{125} \mathrm{I}\right] \mathrm{rT}_{3}$. Serial blood and urine samples were obtained to assess serum disappearance and total deiodination.

$240,300,360,600$, and $720 \mathrm{~min}$ after each injection to determine the disappearance pattern of the labeled $\mathrm{rT}_{3}$. Serial urine samples were collected in 2-liter plastic bottles containing $2 \mathrm{ml}$ of $25 \%$ human serum albumin (Travenol Laboratories, Inc., Glendale, CA) to bind and stabilize excreted thyronines. The collections were made every $2 \mathrm{~h}$ for the first $6 \mathrm{~h}$ and then every $6 \mathrm{~h}$ for the next $24 \mathrm{~h}$ to estimate the total deiodination of the tracer $\mathrm{rT}_{3}$. This 30 -h urinary collection period was utilized as $>90 \%$ of the total ${ }^{125}$ I activity excreted had been recovered. All urine samples were refrigerated during the collection period and stored for processing. All blood samples were allowed to clot fully at room temperature before the serum was separated and stored at $-20^{\circ} \mathrm{C}$ for processing. After the completion of the control period, the subjects were given sequentially PTU ( $300 \mathrm{mg}$ every $6 \mathrm{~h}$ ), DEX ( $2 \mathrm{mg}$ every $6 \mathrm{~h}$ ), and then an oral $3.0 \mathrm{mg} \mathrm{T}_{4}$ load followed by a maintenance dose $(0.30 \mathrm{mg}$ every day). Each study agent was administered for a 3-d period before the $\mathrm{rT}_{3}$ tracer studies to allow peripheral thyronine status to approach a new equilibrium. At least $3 \mathrm{~d}$ were allowed between each study period to minimize the influence of the previous study agent.

Sample processing. To separate labeled thyronines from radioiodine and iodoproteins, the serum samples were processed using $\mathrm{C} 18$ Sep-Pak cartridges (Waters Associates, Milford, MA). Each Sep-Pak cartridge was activated with $10 \mathrm{ml}$ of a $50 \%$ tetrahydrofuran: $20 \mathrm{mM}$ ammonium acetate (THF:NH4Ac) solution followed by $10 \mathrm{ml}$ of $10 \%$ THF:NH4Ac. Serum samples, volumes ranging from 3.0 to $5.0 \mathrm{ml}$, were incubated for 3 min with an equal volume of $0.2 \mathrm{~N} \mathrm{NaOH}$ and passed through an activated Sep-Pak. This was followed by a $5.0 \mathrm{ml}$ wash of $10 \%$ THF:NH4Ac to eliminate radioiodide. The bound radioiodothyronines were then eluted from the Sep-Pak with $4 \mathrm{ml}$ of $50 \%$ THF:NH4Ac and collected in $12 \times 75 \mathrm{~mm}$ culture tubes, and counted on a dual channel gamma counter (TM Analytic, Elk Grove Village, IL). The average recovery of [ $\left.{ }^{125} \mathrm{I}\right] \mathrm{rT}_{3}$ from serum was $85 \pm 1.1 \%$ ( \pm SEM, $n=6$ ). Less than $1 \%$ of the radioiodide, as assessed by sodium ${ }^{131}$ I studies, was recovered in the thyronine elution fraction $(n=6)$. Greater than $99 \%$ of the iodoproteins, as assessed by radiolabeled albumin studies, were recovered in the void volume $(n=6)$. After appropriate corrections for recovery, individual serum tracer $\mathrm{rT}_{3}$ disappearance curves were analyzed by noncompartmental analysis (13).
Serum disappearance curve data were fitted to the sums of two or three exponentials. The data from five of the six curves in each of the control, PTU, DEX, and $\mathrm{T}_{4}$ groups fit the sums of two exponentials better than three. The $\mathrm{rT}_{3}$ production rates were estimated as the product of the metabolic clearance rate and the respective serum $\mathrm{rT}_{3}$ concentration. In addition, mean serum disappearance curves for each of the groups were analyzed by both noncompartmental as well as compartmental calculations (17). The rate constants generated were used to calculate the mean serum $\mathrm{rT}_{3}$ clearance and appearance rates. The urine samples, after acidification to a pH of 3.5 with $1.0 \mathrm{~N} \mathrm{HCl}$, were processed by the identical Sep-Pak method as detailed above to estimate the total radioiodine and radiothyronine content of each urine sample. The average recovery of $\left[{ }^{125} \mathrm{I}\right] \mathrm{rT}{ }_{3}$ from urine was $74.5 \pm 2.5 \%$ ( \pm SEM, $n=6$ ).

Selected serum and urine thyronine Sep-Pak eluates were analyzed by HPLC. Separation of the radiothyronines was accomplished on a reverse-phase $\mathrm{C} 18$ column (Water Associates) run with a gradient system ranging from 16 to $26 \%$ THF:NH4Ac and then purged of any remaining radiothyronines with a 50\% THF:NH4Ac wash. Standards of labeled $\mathrm{rT}_{3}, 3,3^{\prime}$-diiodothyronine $\left(3,3^{\prime}-\mathrm{T}_{2}\right), 3,5,3^{\prime}$-triiodothyronine sulfate, $3,3^{\prime}-\mathrm{T}_{2}$ diiodothyronine sulfate and iodide were run concomitantly in the appropriate media to identify the radiothyronines in the patient sample.

Serum total $\mathrm{T}_{4}, \mathrm{~T}_{3}, \mathrm{rT}_{3}$, and TSH concentrations were determined by previously described radioimmunoassay procedures (6). A highly specific $\mathrm{rT}_{3}$ antibody kindly provided by Dr. Theo J. Visser (Rotterdam, The Netherlands) was employed in the $\mathrm{rT}_{3}$ radioimmunoassay (18).

Statistical analysis was by paired $t$ test and results reported as mean \pm SEM

\section{Results}

Table I summarizes the response of the serum thyroid hormone values after administration of each agent. After $3 \mathrm{~d}$ of PTU treatment, mean serum $T_{4}$ concentrations were not altered relative to control. In contrast, DEX administration decreased the mean serum $T_{4}$ levels while the oral $T_{4}$ load increased serum $T_{4}$ values. PTU administration did not significantly lower the serum $T_{3}$ levels but DEX administration did produce a decrease in $T_{3}$ levels as compared to control. As expected, serum $\mathrm{T}_{3}$ levels were increased with the oral $\mathrm{T}_{4}$ load. Total serum $\mathrm{rT}_{3}$ values were increased by PTU, DEX, and oral $\mathrm{T}_{4}$ administration, as compared to the control group. Of all the agents studied, only oral $\mathrm{T}_{4}$ administration decreased serum TSH levels at the end of the 3-d treatment period as compared to control. Serum $\mathrm{T}_{3} / \mathrm{T}_{4}$ and $\mathrm{rT}_{3} / \mathrm{T}_{4}$ ratios are also shown in Table I. Treatment with PTU did not change the serum $\mathrm{T}_{3} / \mathrm{T}_{4}$ ratio as compared to control. DEX administration also did not decrease the $T_{3} / T_{4}$ ratio despite significantly lowering $T_{3}$

Table I. Serum Thyroid Function Tests

\begin{tabular}{|c|c|c|c|c|c|c|}
\hline Study period & $\mathrm{TT}_{4}$ & $\mathrm{TT}_{3}$ & $\mathrm{~T}_{3} / \mathrm{T}_{4}$ & $\operatorname{TrT}_{3}$ & $\mathrm{rT}_{3} / \mathrm{T}_{4} \times 10^{-3}$ & TSH \\
\hline & nmol/liter & $n m o l / l i t e r$ & & nmol/liter & & $\mu U / m l$ \\
\hline Control & $90.1 \pm 5.5$ & $2.3 \pm 0.1$ & $0.026 \pm 0.002$ & $0.23 \pm 0.02$ & $2.4 \pm 0.12$ & $2.0 \pm 0.4$ \\
\hline PTU & $89.6 \pm 6.3$ & $2.2 \pm 0.1$ & $0.025 \pm 0.001$ & $0.37 \pm 0.04^{*}$ & $3.9 \pm 0.29^{\ddagger}$ & $3.6 \pm 0.8$ \\
\hline DEX & $73.2 \pm 10.2^{*}$ & $1.9 \pm 0.1^{\ddagger}$ & $0.027 \pm 0.002$ & $0.33 \pm 0.03^{\S}$ & $4.7 \pm 0.59^{\S}$ & $1.5 \pm 0.5$ \\
\hline $\mathrm{T}_{4}$ load & $204.2 \pm 11.8^{\prime \prime}$ & $3.3 \pm 0.3^{11}$ & $0.016 \pm 0.002^{\|}$ & $0.40 \pm 0.04^{\top}$ & $2.0 \pm 0.24$ & $<0.01$ \\
\hline
\end{tabular}

Data presented as mean \pm SEM. $\quad \mathrm{TT}_{4}$, total serum $\mathrm{T}_{4}$ concentration; $\mathrm{TT}_{3}$, total serum $\mathrm{T}_{3}$ concentration; $\mathrm{TrT} \mathrm{T}_{3}$, total serum $\mathrm{rT}$ concentration. ${ }^{*} P<0.05,{ }^{\ddagger} P<0.03,{ }^{\S} P<0.04,{ }^{\prime \prime} P<0.005, " P<0.02$. 
values, while oral $T_{4}$ loading did decrease the $T_{3} / T_{4}$ ratio. This latter finding is consistent with the previously reported data showing an "autoregulatory" decrease in $T_{4}$ conversion to $T_{3}$ in man in high $T_{4}$ states $(11,12)$. Both PTU and DEX significantly increased serum $\mathrm{rT}_{3} / \mathrm{T}_{4}$ ratios, while no significant influence on $\mathrm{rT}_{3} / \mathrm{T}_{4}$ was found with the oral $\mathrm{T}_{4}$ load as compared to control.

The mean serum tracer $\mathrm{rT}_{3}$ disappearance curves in each study period are plotted in Fig. 2. Only PTU significantly altered the disappearance pattern of tracer $\mathrm{rT}_{3}$. Estimates of $\mathrm{rT}_{3}$ metabolic clearance rates are summarized in Table II. PTU administration decreased the clearance of tracer $\mathrm{rT}_{3}$ while treatment with DEX and oral $\mathrm{T}_{4}$ load had no significant influence on clearance as compared to control. PTU did not alter the $\mathrm{rT}_{3}$ production rate while $\mathrm{DEX}$ administration increased the daily production rate of $\mathrm{rT}_{3}$ as compared to control. Oral $\mathrm{T}_{4}$ administration substantially increased the daily $\mathrm{rT}_{3}$ production rate.

The mean serum $\mathrm{rT}_{3}$ clearance and production rates as calculated by noncompartmental analysis were compared to the mean serum clearance and appearance rates generated by compartmental analysis. Noncompartmental analysis slightly overestimated serum clearance values in all groups as compared with those generated by compartmental analysis $(8.8 \%$ in normals, $4.5 \%$ with PTU, $2.9 \%$ with DEX, and $7.8 \%$ with $\mathrm{T}_{4}$ ). A similar pattern was seen when mean serum production

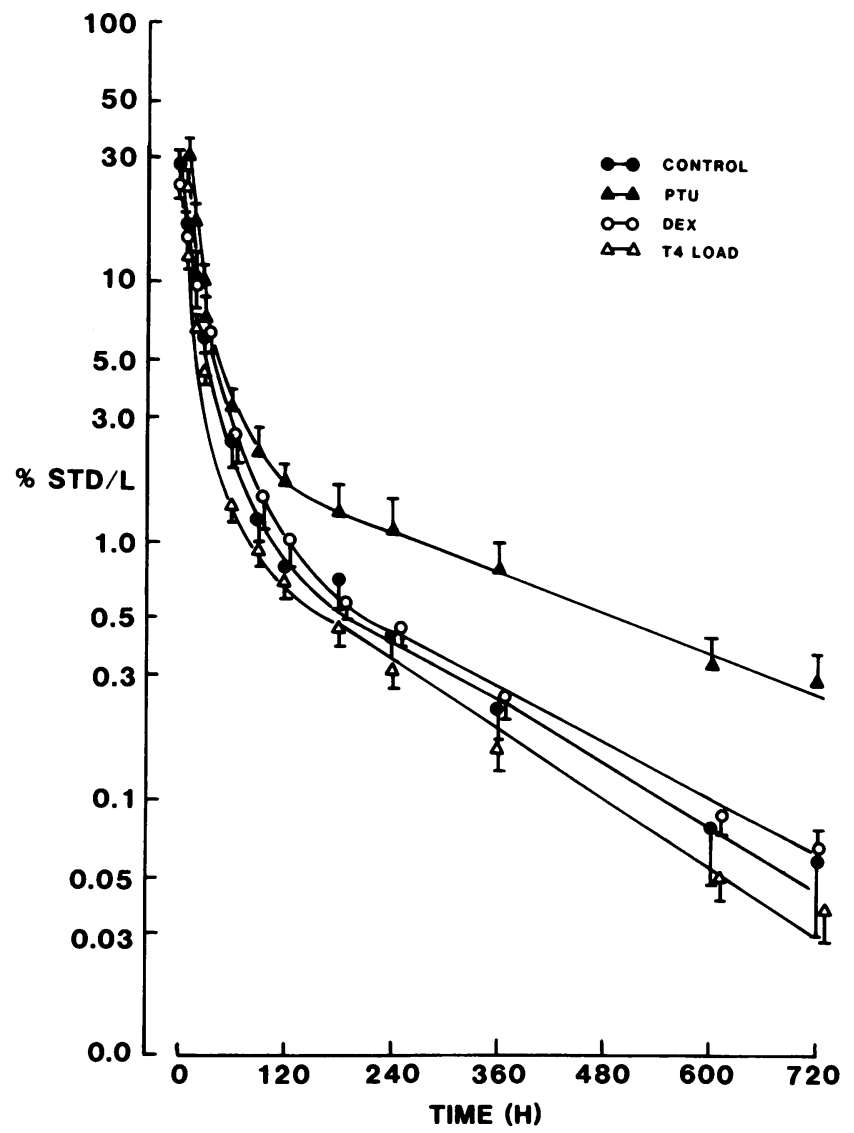

Figure 2. The serum disappearance curve of $\left[{ }^{125} \mathrm{I}\right] \mathrm{rT}_{3}$ in each study group (control •, PTU $\triangle$, DEX $\circ, T_{4} \Delta$ ). The percent dose per liter is plotted against time in minutes. The vertical bar represents mean \pm SEM.
Table II. Serum rT $T_{3} M C R$ and Production Rates

\begin{tabular}{lcc}
\hline Study period & \multicolumn{1}{c}{$\mathrm{rT}_{3} \mathrm{MCR}$} & $\mathrm{rT}_{3} \mathrm{PR}$ \\
\hline & liters $/ d$ & $n m o l / d$ \\
Control & $156.8 \pm 22.3$ & $29.1 \pm 3.4$ \\
$\mathrm{PTU}$ & $105.1 \pm 16.2^{*}$ & $31.5 \pm 4.1$ \\
$\mathrm{DEX}$ & $161.6 \pm 22.7$ & $51.8 \pm 6.2^{*}$ \\
$\mathrm{~T}_{4}$ Load & $187.6 \pm 6.3$ & $69.7 \pm 6.2^{\ddagger}$
\end{tabular}

Data presented as mean \pm SEM.

MCR, metabolic clearance rate; PR, daily blood production rate (MCR $\times$ serum $\mathrm{rT}_{3}$ concentration).

${ }^{*} P<0.02 ;{ }^{\ddagger} P<0.006$.

rates calculated by each method were compared (6.3\% in normals, $6.3 \%$ with PTU, $4.3 \%$ with DEX, and $8.3 \%$ with $\mathrm{T}_{4}$ ).

Estimates of total deiodination of tracer $\mathrm{rT}_{3}$ in each study group are shown in Fig. 3. The fraction of $\mathrm{rT}_{3}$ undergoing deiodination decreased both with PTU administration and after the oral $\mathrm{T}_{4}$ load while treatment with DEX had no effect as compared to control.

Some of the urine samples, after Sep-Pak concentration, were further analyzed by reverse-phase HPLC. Note that the passage of urine through the Sep-Pak eliminated any free radioiodide present. Fig. 4 depicts the elution profile of $\left[{ }^{125} \mathrm{I}\right] \mathrm{rT}_{3}$, $\left[{ }^{125} \mathrm{I}\right] 3,3^{\prime}-\mathrm{T}_{2},\left[{ }^{125} \mathrm{I}\right] 3,5,3^{\prime}$-triiodothyronine sulfate $\left(\mathrm{T}_{3} \mathrm{SO}_{4}\right)$, [25 I] $3,3^{\prime}$-diiodothyronine sulfate $\left(\mathrm{T}_{2} \mathrm{SO}_{4}\right)$, and ${ }^{125} \mathrm{I}-\mathrm{Na}$ when added to an unlabeled urine sample. A representative elution pattern of a patient's urine sample is also shown in Fig. 4 for comparison. Despite the intravenous administration of labeled $\mathrm{rT}_{3}$, no labeled $\mathrm{rT}_{3}$ was detected in the urine. The major urinary peak co-migrated with the $3,3^{\prime}-\mathrm{T}_{2}$ standard and is presumably the primary deiodinative product of $\mathrm{rT}_{3}, 3,3^{\prime}-\mathrm{T}_{2}$. Interestingly, a peak migrating just before the $\mathrm{T}_{3} \mathrm{SO}_{4}$ standard was found suggesting formation of an $\mathrm{rT}_{3}$ conjugate. In this context, Mol and Visser (2) reported that the sulfate of $\mathrm{rT}_{3}$ elutes before $T_{3}$ sulfate when using a similar mobile phase.

In selected serum extracts, HPLC analysis revealed a single peak, which comigrated with the injected $\mathrm{rT}_{3}$ tracer (data not shown). Less than $10 \%$ of labeled $\mathrm{rT}_{3}$ added to urine samples

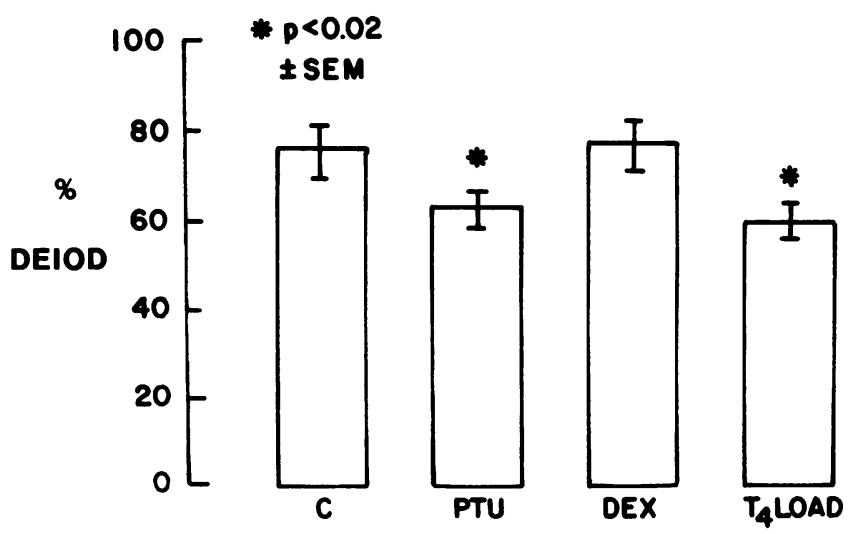

Figure 3. The percentage of total $\mathrm{rT}_{3}$ injected that is recovered in the urine as radioiodine in each study group. Results are presented as mean \pm SEM. 

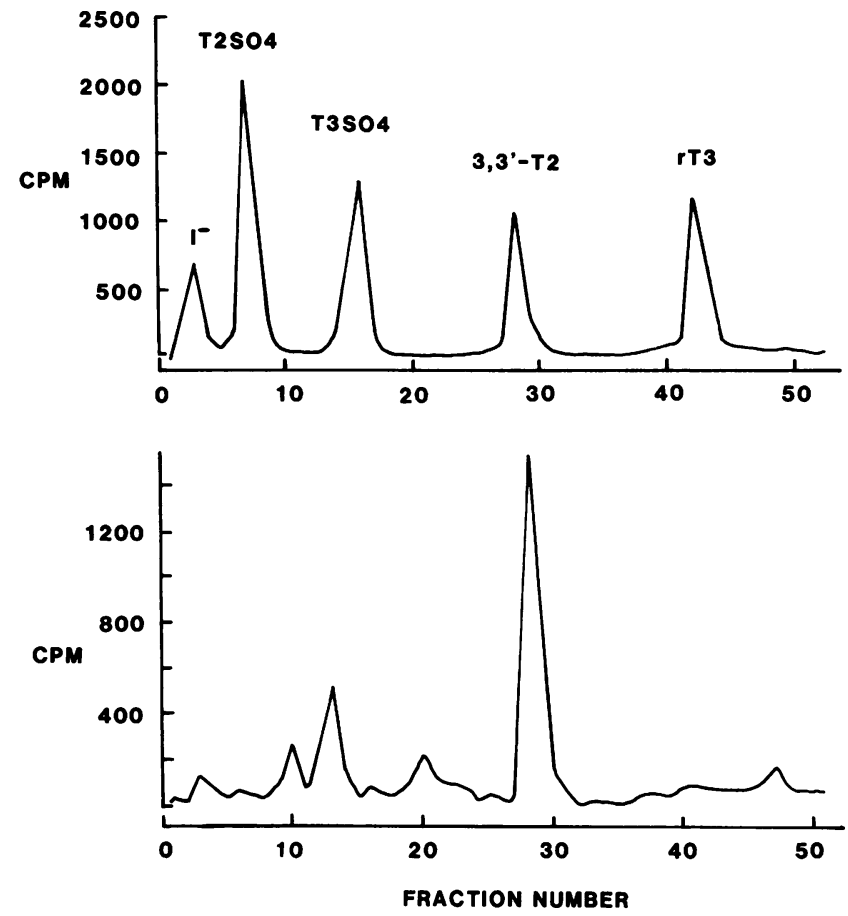

Figure 4. Reverse phase HPLC analysis of a urine labeled with a mixture of ${ }^{125} \mathrm{I}$ labeled NA, $\mathrm{T}_{2} \mathrm{SO}_{4}, \mathrm{~T}_{3} \mathrm{SO}_{4}, 3,3^{\prime}-\mathrm{T}_{2}$ and $\mathrm{rT}_{3}$ (top). The lower panel depicts a reverse-phase HPLC analysis of a Sep-Pak extracted urine sample from a patient receiving intravenous $\left[{ }^{125} \mathrm{I}\right] \mathrm{rT}_{3}$.

was degraded to $3,3^{\prime}-\mathrm{T}_{2}$ and $\mathrm{I}^{-}$as shown by HPLC analysis. The remainder comigrated with the injected tracer (data not shown).

\section{Discussion}

The major finding in the present study was that PTU, DEX, and $T_{4}$ administration all produced significant elevations in serum $\mathrm{rT}_{3}$ levels, but did so by different mechanisms. PTU, a known type I 5'-deiodinase inhibitor slowed the clearance of $\mathrm{rT}_{3}$, which in turn, led to an increase in circulating $\mathrm{rT}_{3}$ and the $\mathrm{rT}_{3} / \mathrm{T}_{4}$ ratio values without altering the daily $\mathrm{rT}_{3}$ production rate (19). This is consistent with the previous work of Kaplan and co-workers who demonstrated that the administration of PTU to $\mathrm{T}_{4}$-replaced hypothyroid patients produced a similar rise in serum $\mathrm{rT}_{3}$ values (20). These changes are also analogous with findings previously described with fasting, liver disease, and nonthyroidal illnesses (13-16). DEX, a previously reported type I 5 -deiodinase inhibitor, also increased the circulating $\mathrm{rT}_{3}$ and $\mathrm{rT}_{3} / \mathrm{T}_{4}$ ratio values (21). However, this appeared not to result from decreased $\mathrm{rT}_{3}$ clearance, but rather from increased $\mathrm{rT}_{3}$ production. $\mathrm{T}_{4}$ administration also increased serum $\mathrm{rT}_{3}$ values presumably by increasing substrate availability $\left(T_{4}\right)$ since serum $r T_{3} / T_{4}$ ratio values and clearance rates remained constant. This confirms the work of Kaplan et al. who showed circulating $\mathrm{rT}_{3}$ values vary directly with serum $\mathrm{T}_{4}$ levels (20).

There were minor but important differences observed in $\mathrm{rT}_{3}$ clearance and production rate estimates in euthyroid subjects. The mean normal $\mathrm{rT}_{3}$ plasma clearance rate of $157 \pm 22$ liters/d observed in this study is slightly higher than the mean values of 76 to 140 liters/d previously reported (22-25). This variance may reflect the improved isolation methods for tracer $\mathrm{rT}_{3}$ from serum employed in this study. Some of the previous isolation techniques may have been hampered by incomplete elimination of radioiodine and iodoprotein during the extraction process (26). In the present study, the use of Sep-Pak processing for tracer $\mathrm{rT}_{3}$ isolation virtually eliminated any contaminating radioiodine and iodoprotein. In turn, this led to a somewhat higher and presumably more accurate $\mathrm{rT}_{3}$ clearance estimate. Despite the somewhat greater $\mathrm{rT}_{3}$ clearance rate values, the calculated mean daily $\mathrm{rT}_{3}$ production rate of 29 $\mathrm{nmol} / \mathrm{d}$ was at the lower end of the previously reported normal range of 26 to $89 \mathrm{nmol} / \mathrm{d}(22-25)$. The principal reason for this finding appears to be that the total serum $\mathrm{rT}_{3}$ values were systemically lower than have been generally reported. This is apparently the result of the highly specific $\mathrm{rT}_{3}$ radioimmunoassay employed in the present study (18). This dependency of serum $\mathrm{rT}_{3}$ estimates on antibody specificity characteristics has been previously documented by Eisenstein and co-workers (15).

This study also may shed light on the source of circulating $\mathrm{rT}_{3}$ in man. It has been postulated that circulating $\mathrm{rT}_{3}$ may arise from the liver as the type I-5'-deiodinase in rat liver is equally adept at removing either an inner or outer ring iodide from $\mathrm{T}_{4}(27)$. However, the subsequent rapid intrahepatic degradation of locally produced $\mathrm{rT}_{3}$ would prevent the liver from being a net exporter of $\mathrm{rT}_{3}$ into the circulation (21). Recent studies by Visser et al. have shown that the 5 -deiodinase located in normal human liver has almost identical enzymatic characteristics to that present in rat liver and would presumably behave in a similar fashion (28). Further, Faber and colleagues, who estimated serum $\mathrm{rT}_{3}$ values in the hepatic artery and portal vein in man, were unable to demonstrate a gradient of $\mathrm{rT}_{3}$ across the liver (29). This suggests that the human liver, like the rat liver, is also not a net producer of circulating $\mathrm{rT}_{3}$. Thus, functionally, the liver acts more as an $\mathrm{rT}_{3}$ disposal organ rather than a producer of $\mathrm{rT}_{3}$.

Perhaps a more likely source of circulating $\mathrm{rT}_{3}$ would be from extrahepatic tissues where $T_{4}$ to $\mathrm{rT}_{3}$ conversion is catalyzed by the so-called type III or 5-deiodinase enzyme system. Such a specific inner ring deiodinase system has been documented in rat skin, brain, and placenta as well as in the human placenta (30-33). Whatever the specific tissue deiodinase system responsible for $\mathrm{rT}_{3}$ generation from $\mathrm{T}_{4}$ in man, it does not appear to be inhibited by PTU since $\mathrm{rT}_{3}$ production rates were not altered by the amount of PTU employed $(1,200 \mathrm{mg} / \mathrm{d})$. It is of interest that such PTU dosages will inhibit $80 \%$ of outer ring $\mathrm{T}_{4}$ deiodination in man (34). Although the lack of PTU inhibition in vivo is consistent with the observations in rat brain and skin in vitro, a possible exception may exist in rat and human placenta where $\mathrm{rT}_{3}$ generation is inhibited $(32,33)$. It would appear that a differential inhibitory effect of PTU exists at various tissue sites. Clarification of this discrepancy will have to await the full biochemical characterization of this enzyme system.

DEX administration had no effect on $\mathrm{rT}_{3}$ clearance, but did increase the total daily $\mathrm{rT}_{3}$ production rate. To our knowledge, this is the first reported instance where increased levels of circulating $\mathrm{rT}_{3}$ resulted from augmented production rather than by decreased clearance. In turn, this suggests that DEX 
may directly stimulate the type III 5-deiodinase. The finding by Osathanondh and colleagues of an increase in amniotic fluid $\mathrm{rT}_{3}$ levels in pregnant women administered DEX is consistent with this observation (35). However, McCann et al. were unable to show any influence of corticosterone acetate on the type III 5-deiodinase system in rat liver in vitro (36). This may reflect either species variability or tissue specific regulation of type III 5-deiodinase enzyme activity.

Both compartmental and noncompartmental analysis of mean serum $\mathrm{rT}_{3}$ tracer disappearance curves were performed in the present study. Computation of blood $\mathrm{rT}_{3}$ clearance rate estimates differed by $<10 \%$ using these two methods. More importantly, these differences did not alter the basic conclusions reached regarding the changes in the calculated $\mathrm{rT}_{3}$ production rates observed in the various study groups. Because of the multiple assumptions required for the compartmental approach (i.e., number of compartments, source of production, sites of degradation, so forth), noncompartmental analysis was used for calculation of the production estimates. Although compartmental analysis may potentially provide some information regarding the source of the increased $\mathrm{rT}_{3}$ production noted with glucocorticoid administration, without independent validation of this model separate from serum $\mathrm{rT}_{3}$ disappearance curves, such analysis would appear to be highly problematical.

The lack of detectable tracer $\mathrm{rT}_{3}$ in the urine as analyzed by HPLC was also a surprising finding. This phenomena was not due to breakdown of $\mathrm{rT}_{3}$ as minimal degradation of labeled $\mathrm{rT}_{3}$ occurred when added to fresh unlabeled urine samples that were incubated at $37^{\circ} \mathrm{C}$ overnight. This observation is consistent with the findings of Rogowski and colleagues and Faber et al. who were unable to detect stable $\mathrm{rT}_{3}$ in urine using a specific radioimmunoassay $(37,38)$. The lack of $\mathrm{rT}_{3}$ in urine may be due to either tubular reabsorption of filtered $\mathrm{rT}_{3}$ and/or rapid deiodination of $\mathrm{rT}_{3}$ by renal tubular 5 -deiodinase enzyme systems (39). The predominance of $3,3^{\prime}-\mathrm{T}_{2}$ in the urinary thyronine metabolite fraction suggests that the tracer $\mathrm{rT}_{3}$ had been deiodinated, which is consistent with the observations in a perfused rat kidney where rapid deiodination of $\left[{ }^{125} \mathrm{I}\right] \mathrm{rT}_{3}$ occurs with the identifiable urinary excretory products being iodide and $3,3^{\prime}, \mathrm{T}_{2}(40)$.

Another somewhat unexpected by-product was the minimal effect that PTU administration had on circulating $T_{3}$ levels and $T_{3} / T_{4}$ ratio values in our subjects. This was surprising since PTU is known to inhibit the hepatic type I-5'-deiodinase system. This contrasts with other studies where dramatic falls in circulating $T_{3}$ and $T_{3} / T_{4}$ ratios have occurred in subjects administered similar doses of PTU. Abuid and Larsen and Croxson et al. observed an $\sim 50 \%$ decrease in circulating $\mathrm{T}_{3}$ levels in hyperthyroid patients administered PTU $(41,42)$. Further, Saberi et al. and Geffner and co-workers showed a less striking decrease of serum $T_{3}$ in $T_{4}$-replaced hypothyroid patients administered up to $1,000 \mathrm{mg}$ of PTU per day $(7,8)$. One possible explanation for the failure of serum $\mathrm{T}_{3}$ concentrations to fall in the present study may be due to a compensatory increase in TSH-mediated $\mathrm{T}_{3}$ secretion by the thyroid gland. However, this seems unlikely as serum TSH levels were only modestly but not significantly increased. Another interpretation would be that the source of circulating $T_{3}$ varies with the level of serum $T_{4}$ concentration (43). Silva et al. have suggested that up to $40 \%$ of the circulating $T_{3}$ in the adult rat is generated from the type II 5'-deiodinase pathway and that an even greater proportion is derived from this pathway in the neonatal rat $(44,45)$. Similar estimates of $T_{3}$ generation in the rat have also been made by DiStefano and colleagues employing kinetic models suggesting that $\sim 50 \%$ of the circulating $T_{3}$ is derived from the so-called "slow pool" where type II 5'-deiodinase enzyme systems predominate (46).

DEX administration also produced lower serum $T_{3}$ values, but did so in proportion to the decline in circulating $T_{4}$ levels. This may reflect a vascular-tissue redistribution effect of DEX on $T_{4}$ and $T_{3}$ rather than an alteration in $T_{4}$ to $T_{3}$ conversion efficiency. This contrasts with the rapid fall in circulating $T_{3}$ levels seen in thyrotoxic Graves' patients treated with DEX (11). Thus, as with PTU, the effectiveness of DEX in lowering $T_{3}$ levels may be related to the circulating $T_{4}$ values. Supporting this view were the findings of Ferguson and Jennings who observed that a marked decrease in the conversion efficiency of $T_{4}$ to $T_{3}$ could only be demonstrated when pharmacological doses of $\mathrm{T}_{4}$ were employed in a perfused liver preparation from DEX-treated rats (47). Cavalieri et al. reported that whole body conversion rates of tracer $T_{4}$ to $T_{3}$ were reduced in intact $\mathrm{T}_{4}$-replaced hypothyroid rats treated with DEX (48). However, these results were complicated by the unexpected alterations in the metabolism of tracer $T_{3}$, including changes in $T_{3}$ distribution and tissue binding as well as slowing of its clearance. This contrasts with the apparent lack of effect that DEX administration has on tracer $T_{3}$ distribution and clearance in man (49). Thus, it would appear that the intact rat and man may not be comparable models in studying the effects of glucocorticoids on peripheral thyroid hormone metabolism.

Clearly the present study revealed that peripheral $\mathrm{rT}_{3}$ metabolism in man is somewhat more complex than has been previously appreciated. Specifically, the source of circulating $\mathrm{rT}_{3}$ most likely orginates from extrahepatic tissues containing the type III 5-deiodinase, that the activity of this enzyme system is not influenced by PTU but stimulated by DEX, and that the proportion of $\mathrm{T}_{4}$ metabolized to circulating $\mathrm{rT}_{3}$ does not vary with substrate availability indicating that this is a low affinity, high capacity enzyme system.

\section{Acknowledgments}

The authors wish to express their appreciation to Mrs. Angel Lai-Rosenfeld for her technical assistance and to Mrs. Denise Walters and Mrs. Anne Santo for their help in the preparation of the illustrations and manuscript.

This work was supported in part by National Institute of Health grants DK11727 and DRR General Clinical Research Center grant RR-43.

\section{References}

1. Engler, D., and A. Burger. 1984. The deiodination of the iodothyronines and of their derivatives in man. Endocr. Rev. 5:151-184.

2. Mol, J. A., and T. J. Visser. 1985. Rapid and selective inner ring deiodination of thyroxine sulfate by rat liver deiodinase. Endocrinology. 117:8-12.

3. Pittman, C. S., T. Shimuzu, A. Burger, and J. B. Chambers, Jr. 1980. The nondeiodinative pathways of thyroxine metabolism: 3,5,3',5'-tetraiodothyroacetic acid turnover in normal and fasting human subjects. J. Clin. Endocrinol. Metab. 50:712-716. 
4. Balsam, A., F. Sexton, M. Borges, and S. H. Ingbar. 1983. Formation of diiodotyrosine from thyroxine. Ether-link cleavage, an alternate pathway of thyroxine metabolism. J. Clin. Invest. 72:12341245.

5. Chopra, I. J., U. Chopra, S. R. Smith, M. Reza, and D. H. Solomon. 1975. Reciprocal changes in serum concentrations of 3,3', $5^{\prime}$-triiodothyronine (reverse $\mathrm{T}_{3}$ ) and 3,3',5-triiodothyronine $\left(\mathrm{T}_{3}\right)$ in systemic illnesses. J. Clin. Endocrinol. Metab. 41:1043-1049.

6. Spencer, C. A., S. M. C. Lum, J. F. Wilber, E. M. Kaptein, and J. T. Nicoloff. 1983. Dynamics of serum thyrotropin and thyroid hormone changes in fasting. J. Clin. Endocrinol. Metab. 56:883-888.

7. Saberi, M., F. H. Sterling, and R. D. Utiger. 1975. Reduction in extrathyroidal triiodothyronine production by propylthiouracil in man. J. Clin. Invest. 55:218-223.

8. Geffner, D. L., M. Azukizawa, and J. M. Hershman. 1975. Propylthiouracil blocks extrathyroidal conversion of thyroxine to triiodothyronine and augments thyrotropin secretion in man. J. Clin. Invest. 55:224-229.

9. Duick, D. S., D. W. Warren, J. T. Nicoloff, C. L. Otis, and M. S. Croxson. 1974. Effect of a single dose of dexamethasone on the concentration of serum triiodothyronine in man. J. Clin. Endocrinol. Metab. 39:1151-1154.

10. Chopra, I. J., D. E. Williams, J. Orgiazzi, and D. H. Solomon. 1975. Opposite effects of dexamethasone on serum concentrations of 3,3', '5'-triiodothyronine (reverse $\mathrm{T}_{3}$ ) and 3,3',5-triiodothyronine $\left(\mathrm{T}_{3}\right) . J$. Clin. Endocrinol. Metab. 41:911-920.

11. Braverman, L. E., A. Vagenakis, P. Downs, A. E. Foster, K. Sterling, and S. H. Ingbar. 1973. Effects of replacement doses of sodium-L-thyroxine on the peripheral metabolism of thyroxine and triiodothyronine in man. J. Clin. Invest. 52:1010-1017.

12. Lum, S. M. C., J. T. Nicoloff, C. A. Spencer, and E. M. Kaptein. 1984. Peripheral tissue mechanism for maintenance of serum triiodothyronine values in a thyroxine-deficient state in man. J. Clin. Invest. 73:570-575.

13. Kaptein, E. M., W. J. Robinson, D. A. Grieb, and J. T. Nicoloff. 1982. Peripheral serum thyroxine, triiodothyronine, and reverse triiodothyronine kinetics in the low thyroxine state of acute nonthyroidal illness. J. Clin. Invest. 69:526-535.

14. Faber, J., H. Francis-Thomsen, I. B. Lumholtz, C. Kirkegaard, K. Sierbach-Nielsen, and T. Friis. 1981. Kinetic studies of thyroxine 3,5,3'-triiodothyronine, 3,3',5'-triiodothyronine, 3',5'-diiodothyronine, $3,3^{\prime}$-diiodothyronine and $3^{\prime}$-monoiodothyronine in patients with liver cirrhosis. J. Clin. Endocrinol. Metab. 53:978-984.

15. Eisenstein, Z., S. Haag, A. G. Vagenakis, S. L. Fang, B. Ransil, A. Burger, A. Balsam, L. E. Braverman, and S. H. Ingbar. 1978. Effects of starvation on the production and peripheral metabolism of 3,3', $5^{\prime}$ triiodothyronine in euthyroid obese subjects. J. Clin. Endocrinol. Metab. 47:889-893.

16. Suda, A. K., C. S. Pittman, T. Shimizu, and J. B. Chambers, Jr. 1978. The production and metabolism of 3,5,3'-triiodothyronine and 3,3',5'-triiodothyronine in normal and fasting subjects. J. Clin. Endocrinol. Metab. 47:1131-1319.

17. Kaptein, E. M., P. M. Egodage, M. T. Hoopes, and A. G Burger. 1988. Amiodarone alters thyroxine transfer and distribution in humans. Metab. Clin. Exp. 37:1107-1113.

18. Visser, T. J., E. Docter, and G. Hennemann. 1977. Radioimmunoassay of reverse triiodothyronine. J. Endocrinol. 73:395-396.

19. Kaplan, M. M. 1984. The role of thyroid hormone deiodination in the regulation of hypothalamo-pituitary function. Neuroendocrinology. 38:254-260.

20. Kaplan, M. M., M. Schimmel, and R. D. Utiger. 1977. Changes in serum $3,3^{\prime}, 5^{\prime}$-triiodothyronine (reverse $T_{3}$ ) concentrations with altered thyroid hormone secretion and metabolism. J. Clin. Endocrinol. Metab. 45:447-456.

21. Balsam, A., and S. H. Ingbar. 1978. The influence of fasting, diabetes and several pharmacological agents on the pathways of thyroxine metabolism in rat liver. J. Clin. Invest. 62:415-424.
22. Chopra, I. J. 1976. An assessment of daily production and significance of thyroidal secretion of 3,3',5'-triiodothyronine (reverse $\mathrm{T}_{3}$ ) in man. J. Clin. Invest. 58:32-40.

23. Corcoran, J. M., and C. J. Eastman. 1977. Reverse triiodothyronine metabolism in euthyroid adults. Horm. Metab. Res. 9:526-527.

24. Gavin, L., J. Castle, F. McMahan, P. Martin, M. Hammond, and R. R. Cavalieri. 1977. Extrathyroidal conversion of thyroxine to 3,3',5'-triiodothyronine (reverse $T_{3}$ ) and to 3,5,3'-triiodothyronine $\left(T_{3}\right)$ in humans. J. Clin. Endocrinol. Metab. 44:733-742.

25. Smallridge, R. C., L. Wartofsky, R. E. Desjardins, and K. L. Burman. 1978. Metabolic clearance and production rate of 3,3',5'triiodothyronine in hyperthyroid, euthyroid, and hypothyroid subjects. J. Clin. Endocrinol. Metab. 47:345-349.

26. Bianchi, R., G. C. Zucchelli, D. Giannessi, A. Pilo, G. Mariani, A. Carpi, and M. G. Toni. 1977. Evaluation of triiodothyronine $\left(T_{3}\right)$ kinetics in normal subjects in hypothyroid and hyperthyroid patients using specific antiserum for the determination of labeled $\mathrm{T}_{3}$ in plasma. J. Clin. Endocrinol. Metab. 46:203-214.

27. Chopra, I. J., and G. N. Teco. 1982. Characteristics of inner ring ( 3 or 5) monodeiodination of 3,5-T2 in rat liver: evidence suggesting marked similarities of inner and outer ring dieodinases for iodothyronines. Endocrinology. 110:89-97.

28. Visser, T. J., E. Kaptein, O. T. Terpstra, and E. P. Krenning. 1988. Deiodination of thyroid hormone by human liver. J. Clin. Endocrinol. Metab. 67:17-24.

29. Faber, J., O. K. Faber, B. Lund, C. Kirkegaard, and J. Warren. 1980. Hepatic extraction and renal production of 3,3'-diiodothyronine in man. J. Clin. Invest. 66:941-945.

30. Huang, T.-S., I. J. Chopra, A. Beredo, D. H. Solomon, and G. N. Chuateco. 1985. Skin is an active site for the inner ring monodeiodination of thyroxine to $3,3^{\prime}, 5^{\prime}$-triiodothyronine. Endocrinology. 117:2106-2113.

31. Kaplan, M., and K. Yaskoski. 1980. Phenolic and tyrosyl ring deiodination of iodothyronines in rat brain homogenates. J. Clin. Invest. $66: 551-562$.

32. Roti, E., S. L. Fang, L. E. Braverman, and C. H. Emerson. 1982. Rat placenta is an active site of inner ring deiodination of thyroxine and 3,3',5-triiodothyronine. Endocrinology. 110:34-37.

33. Fay, M., E. Roti, S. L. Fang, G. Wright, L. E. Braverman, and C. H. Emerson. 1984. The effects of propylthiouracil, iodothyronines, and other agents on thyroid hormone metabolism in human placenta. J. Clin. Endocrinol. Metab. 58:280-286.

34. Nicoloff, J. T. 1970. A new method for the measurement of acute alterations in thyroxine deiodination rate in man. J. Clin. Invest. 49:267-273.

35. Osathanondh, R., I. J. Chopra, and D. Tulchinsky. 1978. Effects of dexamethasone on fetal and maternal thyroxine, triiodothyronine, and reverse triiodothyronine and thyrotropin levels. J. Clin. Endocrinol. Metab. 47:1236-1239.

36. McCann, U. D., E. A. Shaw, and M. M. Kaplan. 1984. Iodothyronine deiodination reaction types in several rat tissues: effect of age, thyroid status, and glucocorticoid treatment. Endocrinology. 114:1513-1521.

37. Rogowski, P., J. Faber, and K. Siersbaek-Nielsen. 1980. Renal handling of 3,3',5'-triiodothyronine (reverse $T_{3}$ ) compared to thyroxine and 3,5,3'-triiodothyronine in different thyroid function states in man. Acta Endocrinol. 94:337-340.

38. Faber, J., M. Busch-Sorensen, P. Rogowski, C. Kirkegaard, K. Siersbaek-Nielsen, and T. Friis. 1981. Urinary excretion of free and conjugated 3',5'-diiodothyronine and 3,3'-diiodothyronine. J. Clin. Endocrinol. Metab. 53:587-593.

39. Chiraseveenuprapund, U., A. Buergi, A. Goswami, and I. N. Rosenberg. 1978. Conversion of L-thyroxine to triiodothyronine in rat kidney homogenate. Endocrinology. 102:612-622.

40. Ferguson, D. C., and H. D. Ross. 1986. Reverse triiodothyro- 
nine $\left(\mathrm{rT}_{3}\right)$ deiodination and fate of formed iodide in the perfused kidney. 68th Endocrine Society. 127 (Abstr.).

41. Abuid, J., and P. R. Larsen. 1974. Triiodothyronine and thyroxine in hyperthyroidism. J. Clin. Invest. 54:201-208.

42. Croxson, M. S., T. D. Hall, and J. T. Nicoloff. 1977. Combination drug therapy for treatment of hyperthyroid Graves' disease. $J$. Clin. Endocrinol. Metab. 45:623-630.

43. Nimalysuriya, A., S. Lin, J. LoPresti, A. Marcus, C. Spencer, and J. T. Nicoloff. 1985. Evidence for dual peripheral $5^{\prime}$-deiodinases $\left(5^{\prime}-D\right)$ regulating circulating $T_{3}$ levels in man. 9th Int. Thyroid Congress. 152 (Abstr.).

44. Silva, J. E., M. B. Gordon, F. R. Crantz, J. L. Leonard, and P. R. Larsen. 1984. Qualitative and quantitative differences in the pathways of extrathyroidal triiodothyronine generation between euthyroid and hypothyroid rats. J. Clin. Invest. 73:898-907.

45. Silva, J. E., and P. S. Mathews. 1984. Thyroid hormone metab- olism and source of plasma triiodothyronine in 2-week old rats: effect of thyroid status. Endocrinology. 114:2394-2405.

46. DiStefano, J. J., III, M. Jang, T. K. Malone, and M. Broutman. 1982. Comprehensive kinetics of triiodothyronine production, distribution, and metabolism in blood and tissue pools of the rat using optimized blood sampling protocols. Endocrinology. 110:198-213.

47. Jennings, A. S., and D. C. Ferguson. 1984. Effect of dexamethasone on triiodothyronine production in the perfused rat liver and kidney. Endocrinology. 114:31-36.

48. Cavalieri, R. R., J. N. Castle, and F. A. McMahon. 1984. Effects of dexamethasone on kinetics and distribution of triiodothyronine in the rat. Endocrinology. 114:215-221.

49. Croxson, M. S., D. S. Duick, and J. T. Nicoloff. 1976. Effect of glucocorticoids on serum triiodothyronine (T3) concentrations in man. In Thyroid Research. J. Robbins and L. E. Braverman, editors. Excerpta Medica/American Elsevier, New York. 266-269. 